\title{
Daya Saing Destinasi MICE di Indonesia
}

\author{
Heri Setyawan \\ Program Studi MICE Politeknik Negeri Jakarta \\ heri.setyawan@bisnis.pnj.ac.id
}

\begin{abstract}
This article discusses the types of tours with visitors who have business needs (business visitor). Tour with visitor aimed at business (MICE / business visitor) different from facet needs, handling with tour with visitor aim of recreation (leisure visitor). In terms of foreign exchange earnings that affect the economic sector is the reason, because spending MICE / business visitor is greater than the visitors with recreation purposes. The analysis of the discussion refers to the ICCA (International Congress and Convention Association) ranking. The findings suggest that the competitiveness of Indonesian MICE destinations and MICE city in Indonesia is still weak compared to neighboring countries of Singapore, Thailand and Malaysia. In order to competitiveness of MICE destinations in Indonesia, there are four factors that must be considered in the criteria and indicators of a MICE destination. These factors are accessibility, attraction, amenitas as well as human resources and stakeholder support. So that a region / region / city does not easily declare itself as a MICE destination.
\end{abstract}

Keywords: daya saing, destinasi MICE, Indonesia 


\section{Pendahuluan}

Ranking devisa sektor pariwisata dari tahun ke tahun mengalami peningkatan. Pada tahun 2011, devisa sektor pariwisata berada pada urutan kelima dengan devisa USD 8,554.39 juta dibawah minyak dan gas bumi, batu bara, minyak kelapa sawit dan karet olahan. Walaupun pada tahun 2012 urutan devisa sektor pariwisata tetap kelima, namun ada peningkatan jumlah devisa yaitu sebesar USD 9,120.85 juta. Seiiring dengan peningkatan devisa sektor ini, maka pada tahun 2013 (USD 10,054.15 juta), 2014 (USD 11,166.13 juta) dan 2015 (USD 12,225.89) sektor pariwisata menduduki urutan ke 4 (Kemenpar.go.id).

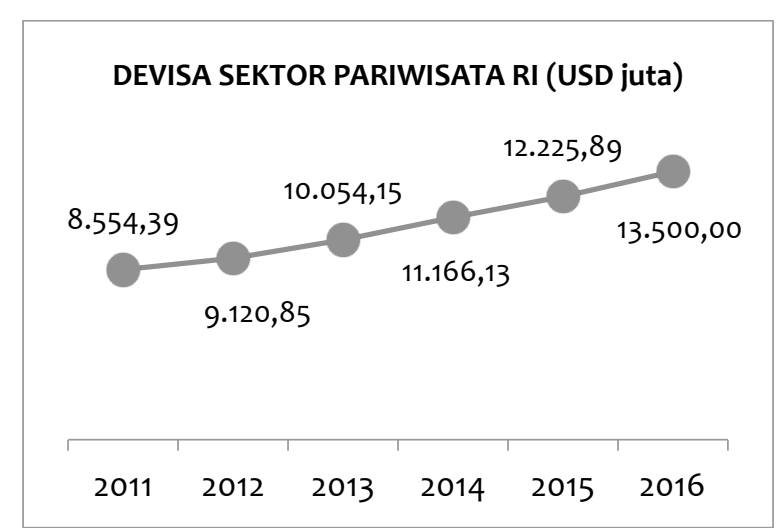

Gambar 1. Devisa Sektor Pariwisata RI Sumber: Kemenpar.go.id, 2017

Pendapatan sektor Pariwisata pada tahun 2016 melonjak menjadi penyumbang urutan kedua sebesar USD 13,5 juta setelah minyak sawit (Kompas.com; detik.com). Pengunjung ke suatu destinasi dapat dikategorikan menjadi dua kelompok besar, yaitu leisure visitor dan business visitor. Pertama, leisure visitor berkunjung ke suatu destinasi mempunyai motivasi untuk rekreasi. Kedua, pada kunjungan business visitor mempunyai motivasi untuk melakukan urusan tertentu (business), misalnya mengikuti kegiatan konferensi, seminar, pameran, dan lain- lain. Kelompok kedua ini termasuk dalam industri MICE atau Meeting industry atau disebut juga Event Business. (Redor,2016) Industri Pertemuan atau lebih dikenal dengan istilah MICE merupakan singkatan dari Meeting, Incentive Travel, Conference, dan Exhibitions. Menurut World Tourism Organisation, Meeting dan business events ini adalah kegiatan wisata yang yang memberikan kontribusi yang signifikan terhadap Gross Domestic Product bagi suatu Negara dan daerah serta dapat menjadi branding bagi suatu destinasi (UNWTO,2016).

Pentingnya membidik pengunjung bisnis/MICE seperti dikemukakan oleh Taleb Rifai (Sekjen UNWTO): “In addition to important business opportunities, the Meetings Industry provides immense benefits to the broader economy as it generates on average a higher spending level, reduces seasonality, contributes to the regeneration of destinations, spreads knowledge and enhances innovation and creativity" (UNWTO,2014). Selain pengunjung membelanjakan lebih besar, dapat menutupi pada low season, berkontribusi memperbarui destinasi, menyebarkan pengetahuan dan meningkatkan inovasi dan kreativitas.

Sebagai bahan perbandingan, pengeluaran pengunjung bisnis/MICE di Thailand 3,5 kali pengunjung leisure (Khaul,2016)

\section{Metode}

Penulis menggunakan metode penelusuran referensi terkait MICE sebagai bahan studi pustaka. Analisis deskriptif dilakukan untuk melihat daya saing destinasi MICE Indonesia mengacu kepada ICCA (International Congres and Convention Association). 


\section{Hasil dan Pembahasan}

\section{Indonesia dalam Trend Dunia MICE}

Berdasarkan rangking ICCA (International Congress and Convention Association) Indonesia sebagai destinasi MICE selalu tertinggal dibandingkan dengan negara tetangga di ASEAN. Kita selalu berada pada urutan dibawah Singapura, Thailand dan Malaysia. Pada tahun 2016 Indonesia berada pada urutan 40 dengan jumlah 94 pertemuan, sementara Thailand (24), Singapura (28) dan Malaysia (35) dengan jumlah pertemuan diatas 100 event.

Mengapa menggunakan ICCA ranking untuk mengukur kekauatan daya saing ?

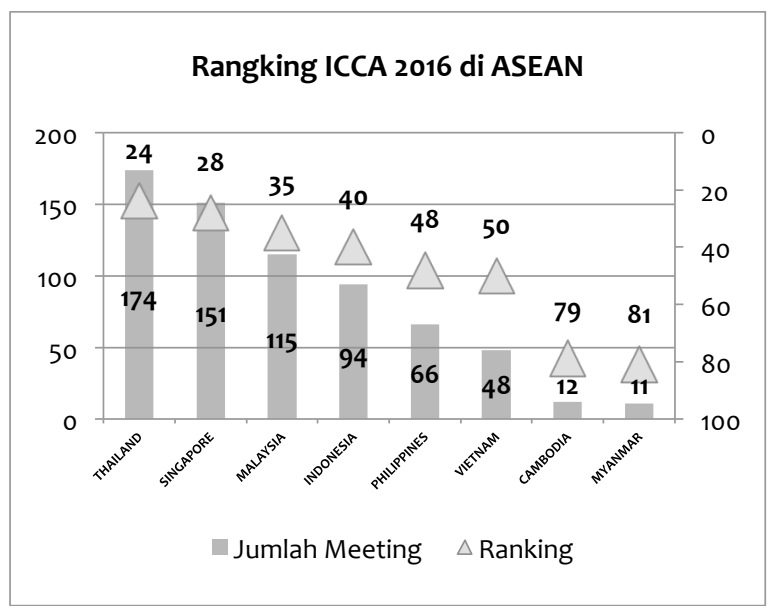

Gambar 2. Ranking ICCA di ASEAN, 2016 Sumber: ICCA, 2017

ICCA membuat rangking berdasarkan kriteria pertemuan antara lain: merupakan association meeting (bukan corporate meeting), dilakukan melalui bidding, minimal 50 peserta, pertemuan dilakukan secara berkala pada 3 negara berbeda. Pertemuan karena diberikan secara jatah tidak diperhitungkan dalam rangking ICCA ini (ICCA,2017).
Rangking Indonesia pada ICCA 2010-2016

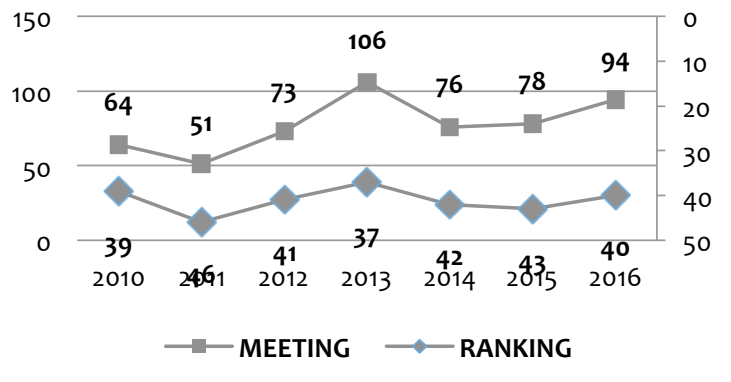

Gambar 3. Ranking Indonesia ICCA 20102016

Sumber: ICCA, 2017

Berdasarkan tabel 3, bisa dilihat bahwa urutan rangking Indonesia tidak terlalu meningkat secara signifikan, bahkan naikturun diangka 40an. Indonesia pernah pada posisi urutan 39 (2010), tahun berikutnya (2011) anjlok ke urutan 46 , naik lagi ke urutan 41 (2012) dan puncaknya pada tahun 2013 yaitu di urutan 37 dengan jumlah pertemuan menembus angka diatas 100 event, persisnya 106 pertemun. Namun pada 2014 dan 2015 mengalami penurunan kembali, yaitu urutan 42 dan 43. Baru pada tahun 2016 ada kenaikan menjadi posisi 40, walaupun dengan jumlah pertemuan dibawah 100, yaitu 94 event.

\section{Faktor Penentu Menjadikan Destinasi MICE}

Destinasi MICE mempunyai karakteristik yang berbeda dengan destinasi leisure akibat dari pengunjung yang berbeda. Kebutuhan pengunjung tidak sama karena motivasi berkunjung yang berbeda. Kebutuhan untuk mengadakan pertemuan paling utama adalah tempat penyelenggaraannya (venue), bukan alam yang indah seperti kebutuhan berekreasi. Namun alam yang indah bisa menjadi nilai tambah bagi destinasi yang sudah 
mempunyai venue, aksesibilitas dan infrakstruktur yang dibutuhkan.

Menurut penelitian Crouch \& Richie (1998), kriteria yang digunakan oleh pihak pengambil keputusan dalam asosiasi dan para perencana pertemuan adalah atributatribut: (1) Aksesibilitas, (2) Dukungan Lokal, (3) Dukungan ekstra selama konferensi, (4) Fasilitas Akomodasi, (5) Fasilitas Pertemuan, (6) Informasi, (7) Lingkungan lokasi pertemuan (8) Kriteria lain.

Tahun 2007, Sanjay Nadkarni dan Aliana Leong Man Wai menulis “Macao's MICE Dream: Opportunities and Challenges" yang dimuat pada International Journal of Event Management Research, volume 3, no.2, 2007 menemukan atribut kritis untuk menjadi destinasi MICE. Atribut-atribut tersebut adalah: (1) MICE facilities and lodging, (2) Cost \& affordability, (3) Leisure and entertainment facilities, (4) Service \& professionalism, (5) Infracstructure \& accessibility, (6) Business-friendliness \& image, dan (7) Government support.

Sementara Indonesia, dalam hal ini Kementerian Pariwisata RI menetapkan ada 16 destinasi MICE yang tersebar dan belum secara serius disiapkan. Ke enambelas destinasi tersebut adalah: Jakarta, Bali, Surabaya, Medan, Batam, Padang, Bandung, Yogyakarta, Semarang Makassar, Manado, Lombok, Solo, Bintan, Palembang dan Balikpapan. Ternyata dari 16 destinasi tersebut, hanya Bali dan Jakarta secara konsisten masuk urutan ICCA. Sedangkan 2 destinasi lainnya Yogyakarta dan Bandung kadang muncul.

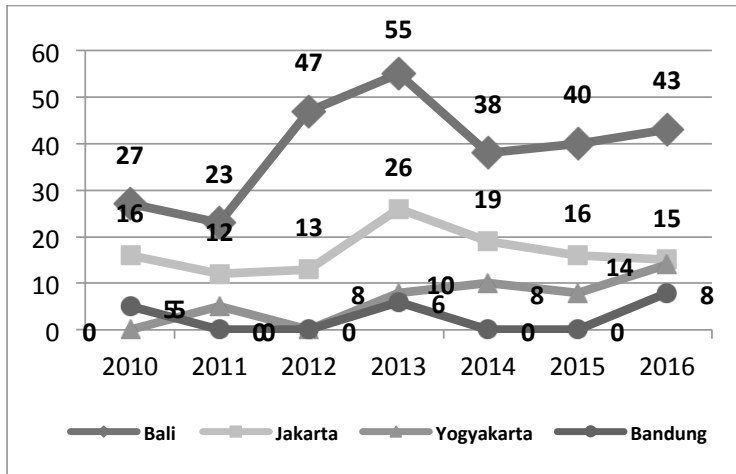

Gambar 4. Jumlah Meeting Destinasi Indonesia dalam ICCA 2010-2016 Sumber: ICCA, 2017

Diantara ke empat destinasi MICE yang masuk urutan ICCA 2010-106, Bali menduduki teratas, tertinggi pada tahun 2012 dengan 55 jumlah pertemuan, tahun lainnya berkisar 40an, tepatnya pada tahun 2015 berjumlah 40 dan 201643 pertemuan. Namun masih dibawah Bangkok yang pada tahun 2015 berjumlah 103 pertemuan dan tahun 2016 berjumlah 121. Sementara Kuala Lumpur pada tahun 2015 berjumlah 73 dan 2016 berjumlah 68 pertemuan. Manila yang pada 2010-2015 selalu dibawah Bali, pada tahun 2016 menyalip dengan 46 jumlah pertemuan (urutan 56).

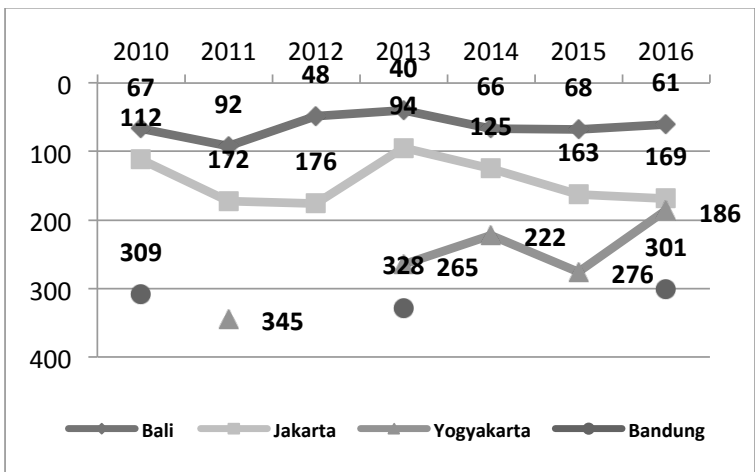

Gambar 4. Ranking Destinasi Indonesia dalam ICCA 2010-2016

Sumber: ICCA, 2017 
Jika dilihat dari urutan pada ICCA 20102016, disamping Bali dan Jakarta yang selalu masuk dalam urutan ICCA, Yogyakarta pada 2010, 2012 tidak ada dalam urutan, ada pada tahun 2011 (urutan 345), 2013 (265), 2014 (222), 2015 (276) dan naik pada 2016 (186). Sedangkan Bandung selama kurun 2010-2016, hanya muncul pada tahun 2010 (urutan 309), 2013(328) dan 2016(301).

\section{Meningkatkan Daya Saing Destinasi MICE}

Menjadi destinasi MICE bukanlah takdir yang datang begitu saja. Berbeda jika kita dikarunia alam yang indah atau budaya adiluhung yang dapat menjadi tujuan wisata rekreasi. Menjadi destinasi MICE tidak cukup karena alam yang indah dan budaya adilung saja. Namun seperti Bali yang awalnya dikenal sebagai destinasi leisure yang terkenal di dunia, lambat laun menjadi destinasi MICE. Bali melengkapi dengan sarana dan fasilitas untuk pertemuan dengan skala internasional, misalnya Bali Nusa Dua Convention Center. Namun tidak untuk Jakarta, karena bukan sebagai destinasi leisure, maka fasilitas pertemuan yang lengkap menjadi daya tarik utamanya. Tersedianya fasilitas pertemuan berskala besar, seperti Jakarta Convention Center adalah salah satu alasan mengapa Jakarta menjadi destinasi MICE utama di Indonesia setelah Bali.

Untuk meningkatkan daya saing destinasi MICE di Indonesia, pada tahun 2017 Indonesia mengeluarkan Peraturan Menteri Pariwisata RI nomor 5 tahun 2017 tentang Pedoman Destinasi Penyelenggaraan Pertemuan, Perjalanan Insentif, Konvensi dan Pameran. Permen tersebut memberikan panduan bagi daerah/kota/wilayah yang ingin menjadi destinasi MICE yang mempunyai daya saing. Pada peraturan tersebut tercantum
4 faktor kriteria yang masing-masing dijelaskan dengan mengukur melalui indikator yang tersedia. Keempat faktor kriteria itu adalah Aksesibilitas MICE, Atraksi (Daya tarik) MICE, Amenitas MICE, serta Sumber daya manusia dan dukungan stakeholder MICE.

Faktor kriteria pertama, Aksesibilitas MICE adalah bagaimana mempermudah lalu lintas orang dan barang dari dan ke suatu destinasi. Kriteria ini mempunyai beberapa indikator anta lain bandara internasional, biaya, jadwal, frekuensi, kenyamanan transit, pelayanan pabean, imigrasi dan karantina (CIQ), dan konektivitas bandara. Faktor kedua yaitu Atraksi MICE. Daya tarik disini bukan alam yang indah, melainkan fasilitas-fasilitas pertemuan maupun pameran. Yang termasuk dalam indikator atraksi disini antara lain fasilitas pertemuan, pameran, akomodasi dengan berbagai variasi dan kapasitas venue, serta tempat-tempat menarik. Suatu kegiatan MICE yang dicari pertama kali adalah bukanlah alam yang indah, melainkan venue mana yang dapat menampung kegiatan MICE tersebut. Venue kegiatan MICE mempunyai standar tersendiri yang sangat kompleks. Namun banyak venue (baik stand alone venue maupun hotel) di Indonesia yang menggunakan klaim Convention Center, ternyata hanyalah sebuah gedung serbaguna yang belum memenuhi standar venue MICE. Oleh karena itu, pemerintah mengeluarkan Peraturan Menteri Pariwisata nomor 2 tahun 2017 tentang Pedoman Tempat Penyelenggaraan Kegiatan (Venue) Pertemuan, Perjalanan Insentif, Konvensi dan Pameran.

Ketiga, faktor yang menunjukkan kriteria Amenitas MICE yang mempunyai indikator terkait keadaan lingkungan dan citra destinasi. 
Sedangkan faktor keempat, adalah kriteria Sumber daya manusia dan stakeholder MICE. Indikator dari kriteria ini adalah ketersediaan dan profesionalitas sumber daya manusia bidang MICE serta dukungan yang diberikan oleh stakeholder jika ada kegiatan MICE. Dukungan stakeholder sangat diperlukan, misalnya regulasi pemda terkait penyelenggaraan kegiatan MICE, dan lembaga pemasar destinasi MICE, yang seharusnya dimiliki oleh setiap destinasi MICE. Lembaga pemasar destinasi MICE, biasanya menggunakan Convention \& Exhibition Bureau yang merupakan kumpulan dari semua stakeholder yang terlibat dalam penyelenggaraan kegiatan MICE. Di Indonesia sebenarnya baru ada satu, yaitu Jakarta Convention \& Exhibition Bureau. Bahkan untuk level nasional sudah dibentuk INACEB (Indonesia Convention and Exhibition Bureau) yang berkedudukan di Jakarta. Suatu destinasi yang mempunyai Covention \& Exhibition Bureau, diharapkan menjadi one stop shopping bagi buyers (assosiasi, korporasi, pemerintah, dll) yang akan menjadikan destinasinya sebagai tuan rumah bagi penyelenggaraan kegiatan MICE.

Mengapa diperlukan Biro Konvensi dan Pameran bagi suatu destinasi ? Karena untuk membidik pasar yang berbeda dari wisata leisure. Membidik pasar MICE mempunyai cara dan strategi yang sangat berbeda dan spesifik, karena yang dibidik bukan orang per orang melainkan group dari asosiasi-asosiasi baik industri maupun profesi, korporasi atau pemerintah. Sehingga tidak bisa disama-ratakan dengan cara membidik wisatawan leisure. Dengan keluarnya Permen Pariwisata nomor 5 tahun 2017 tersebut, maka suatu daerah/wilyah dapat melakukan self assessment untuk mengukur kekuatan apakah layak menjadi destinasi MICE. Sehingga klaim destinasi MICE tidak hanya sebatas pengkuan diri sendiri, namun juga diakui oleh stakeholder lainnya bahkan calon klien yang akan menggunakan destinasi tersebut tidak akan kecewa.

\section{Kesimpulan}

Daya saing destinasi Indonesia masih lemah, jika dibandingkan negara-negara tetangga, dibawah Singapura, Thailand, dan Malaysia.

Begitu juga kota-kota sebagai destinasi MICE di Indonesia, hanya Bali dan Jakarta yang selalu masuk pada urutan ICCA, Yogyakarta dan Bandung belum stabil.

Sudah seharusnya ketika suatu destinasi mencanangkan menjadi destinasi MICE, maka perlu mengkaji terlebih dahulu. Sebagai acuan bagi destinasi tersedia Peraturan Menteri Pariwisata RI nomor 5 tahun 2017.

\section{DaftarPustaka}

Crouch, Geoffrey I, and JR Brent Ritchie.1998. "Convention Site Selection Research: A Review, Conceptual Model and Proposional Framework". Journal of Convention and Exhibition Management, Vol.1, No.1, 1998

ICCA.2017. ICCA Statistics Report: Country and City Rankings 2016.

Indonesia Promosikan 16 Destinasi Wisata MICE di Fankfrut. Retrieved Dec 12, 2017 from http://www.beritasatu.com/foodtravel/430113-indonesia-promosikan16-destinasi-wisata-mice-difrankfurt.htmKhaul, Abhineet.2016. "What will You Get from Organizing a Convention ?". Frost \& Sullivan

Kementerian Pariwisata RI.2017. "Peraturan Menteri Pariwisata RI Nomor 2 Tahun 2017 Tentang Pedoman Tempat 
Penyelenggaraan Kegiatan (Venue) Pertemuan, Perjalanan Insentif, Konvensi dan Pameran". Jakarta: Kemenpar.

Kementerian Pariwisata RI.2017. "Peraturan Menteri Pariwisata RI Nomor 5 Tahun 2017 Tentang Pedoman Destinasi Penyelenggaraan Pertemuan, Perjalanan Insentif, Konvensi dan Pameran". Jakarta: Kemenpar.

Redor, B. 2016. "IQM for MICE Destinations: A Key to Success, a presentation from the UNWTO International Conference on Integrated Quality Management in Tourism Destinations: A Key to Competitiveness". Retrieved August 29, 2016 from http://cf.cdn.unwto.org /sites/all/files/pdf/session_2_bruce_re dor_quality_in_meetings_industry_to urism_france.pdf

UNWTO.2014. "Global Report on the Meeting Industry 2014". Madrid: UNWTO

UNWTO.20016. "Measuring the Economic Importance of the Meeting Industry: Developing a Tourism Satellite Account Extension". Madrid: UNWTO

WTTC.2016. Travel \& Tourism: "Global Economic Impact \& Issue 2017”.
Kompas.com. 3 Tahun Jokowi-JK, Pariwisata Sumbang Devisa Terbesar Kedua. Retrieved Oct 17, 2017, from http://ekonomi.kompas.com/read/201 7/10/17/220236426/3-tahun-jokowi-jkpariwisata-sumbang-devisa-terbesarkedua

Detik.com. Tahun Jokowi-JK, Pariwisata Sumbang Devisa Terbesar Kedua. Retrieved Oct 17, 2017, from https://finance.detik.com/beritaekonomi-bisnis/3687715/tiga-tahunjokowi-jk-pariwisata-sumbang-devisaterbesar-kedua

Kemenpar. Rangkin Devisa Pariwisata Terhadap Komoditas Ekspor Lainnya. Retrieved Oct 17, 2017, from http://www.kemenpar.go.id/asp/detil. asp?c=117\&id $=1198$

https://www.iccaworld.org/dbs/asiapacific/file s/\%20ICCA\%20Thailand\%20Bidding\%20 Workshop\%202016/Abhineet_Edited\% 20Presentation\%20Meeting\%20Impact _ICCA\%20Thai\%20Bid\%20Seminar\%202 016.pdf

http://invest-islands.com/indonesia-micedestinations-imex-frankfurt/ 